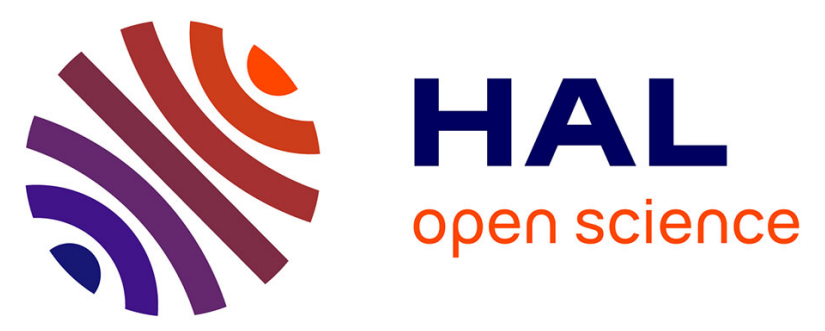

\title{
Influence of proteins and humic-like substances from soluble microbial products on membrane bioreactor fouling under normal and stress conditions
}

Maud Villain-Gambier, Isabelle Bourven, Gilles Guibaud, Benoît Marrot

\section{To cite this version:}

Maud Villain-Gambier, Isabelle Bourven, Gilles Guibaud, Benoît Marrot. Influence of proteins and humic-like substances from soluble microbial products on membrane bioreactor fouling under normal and stress conditions. Process Biochemistry, 2019, 78, pp.140-147. 10.1016/j.procbio.2019.01.012 . hal-02176976

\section{HAL Id: hal-02176976 \\ https://hal.science/hal-02176976}

Submitted on 22 Oct 2021

HAL is a multi-disciplinary open access archive for the deposit and dissemination of scientific research documents, whether they are published or not. The documents may come from teaching and research institutions in France or abroad, or from public or private research centers.
L'archive ouverte pluridisciplinaire HAL, est destinée au dépôt et à la diffusion de documents scientifiques de niveau recherche, publiés ou non, émanant des établissements d'enseignement et de recherche français ou étrangers, des laboratoires publics ou privés.

\section{(c) (1) $\$$}

Distributed under a Creative Commons Attribution - NonCommerciall 4.0 International 


\title{
Influence of proteins and humic-like substances from soluble microbial products on membrane bioreactor fouling under normal and stress conditions
}

\author{
Maud VILLAIN-GAMBIER ${ }^{\text {a,b }}$, Isabelle BOURVENc, Gilles GUIBAUDc, Benoît \\ MARROT $^{\mathrm{a}}$
}

aAix-Marseille Université, CNRS, M2P2 UMR 7340, 13545, Aix en Provence, France.

${ }^{b}$ Laboratoire de Reconnaissance et Procédés de Séparation Moléculaire (RePSeM), Université de Strasbourg, Institut Pluridisciplinaire Hubert Curien (IPHC), UMR CNRS 7178, 25 rue Becquerel, 67087 Strasbourg Cedex 2, France

${ }^{\text {c } U n i v e r s i t e ́ ~ d e ~ L i m o g e s, ~ G R E S E ~ E A ~ 4330, ~} 123$ avenue Albert Thomas, 87060 Limoges, France.

*corresponding author: maud.villain@unistra.fr ; phone number: + 33368852748 


\begin{abstract}
Soluble microbial products are one of the major fouling agents in membrane bioreactor (MBR). It is accepted that high molecular weights polysaccharides are the main contributors to membrane fouling but the presence in bulk solution of proteins and humic-like substances make fouling layer more complex. To better understand the role of both components in fouling establishment, they were quantified and characterized in bioreactor and permeate under various operating conditions (sludge retention time (SRT), synthetic or real wastewater (SWW or RWW), rapid variation of food to microorganisms (F/M) ratio). With SWW at hydraulic retention time (HRT) of $24 \mathrm{~h}$, a larger part of proteins possessing small molecular weights $(<1 \mathrm{kDa})$ were obtained with increasing SRT from 20 to $50 \mathrm{~d}$. At $50 \mathrm{~d}$, these proteins present better retention (93\%) and could participate in lowering gel layer porosity. MBR operating at SRT of $20 \mathrm{~d}$ was then preferable. At respective SRT and HRT of $50 \mathrm{~d}$ and $24 \mathrm{~h}$ with SWW, F/M ratio decrease (from 0.2 to $0.1 \mathrm{~kg}$ COD.kgMLVss ${ }^{-1} \cdot \mathrm{d}^{-1}$ during $24 \mathrm{~h}$ ) provoked implementation of a compact fouling layer which provoked a high TMP increase $\left(0.83 \mathrm{kPa} \cdot \mathrm{h}^{-1}\right)$.

Biodegradation of proteins involved in bio clusters structures were implied in this phenomenon.
\end{abstract}

Keywords: soluble microbial products, proteins, humic-like substances, membrane fouling, operating conditions 


\section{Introduction}

Membrane fouling remains the most challenging issue in MBR application [1]. In its general conception, membrane fouling could be fractionated in different types as pore clogging, gel layer, cake layer and changes of cake layer [2].Extra polymeric substances (EPS) in their bound form or free in the bulk solution as soluble microbial products (SMP) are considered as the main foulants of membrane used in MBR systems [3]. The composition of fouling presents spatial and time related variations as a result of SMP transfer from bulk solution to the membrane, the release of biopolymers by dead cells and the biodegradation of SMP or biopolymers by live cells [4]. SMP compounds were discovered to be the main contributor of membrane initial fouling (i.e. before the TMP jump) whereas EPS were found to be the major foulant after the TMP jump [5]. Membrane fouling due to polymeric substances is mainly composed of polysaccharides, proteins and humic-like substances. Since around ten years [3], it is well established that polysaccharides possess high molecular weights (MW) (>100 kDa) and can be considered as the main compound of biopolymers highly involved on membrane fouling. In association with their high MW, the gelling properties of polysaccharides are strongly implied in increasing fouling resistance. With relatively high SMP content, gel layer could be more easily formed than cake layer and could provoke 100 times higher specific filtration resistance (SFR) [2]. This gel layer was characterized with a high porosity, where proteins could be embedded and its SFR increased with its thickness [6]. Proteins and humic-like substances possess lower MWs but they are also involved in membrane fouling, making it more complex. Because this mixed foulants system could provoke a synergistic effect of membrane fouling [7], it is of practical interest to 
better characterized proteins and humic-like substances to understand their role in membrane fouling in order to control their propensity.

The aim of the present study was therefore to characterize proteins and humic-like substances with the measurement of their concentrations in SMP from bulk solution, permeate, their retention rate and their MWs under varying operating conditions to know their impact in membrane fouling.

Operating conditions such as sludge retention time (SRT), hydraulic retention time (HRT) and food to microorganisms ratio (F/M ratio) are known to influence SMP production and composition. Many studies assessed the role of variable SRT in SMP characteristics and membrane fouling [8-11]. Most of the literature reports that SMP concentration decreased with increasing SRT [3] implying that MBR have to operate above SRT of 15-20 d to control SMP concentration. However, in most of these studies, one MBR system was used and SRT was progressively increased with a reduction of sludge extraction. Thus MLSS concentration increased. As substrate composition and species concentrations are let constant, F/M ratio progressively decreased with increasing SRT. Therefore to clearly elucidate the role of SRT on SMP production and consequences in membrane fouling, studies at constant $\mathrm{F} / \mathrm{M}$ ratio have to be performed. The optimum SRT of MBRs should be included in the range 20-50 d in order to maintain high removal rates and limit membrane fouling [3]. With synthetic wastewater (SWW), at constant F/M ratio of $0.2 \mathrm{~kg}$ CoD. $\mathrm{kg}_{\mathrm{MLVSS}}{ }^{-1} \cdot \mathrm{d}^{-1}$, two campaigns were realized at SRT of 20 or $50 \mathrm{~d}$ to assess impact of proteins and humic-like substances characteristics variations on membrane fouling. In their review of 2017, Meng et al. [4] mentioned that investigations have to be done to better understand changes of sludge properties and membrane performance occurring after naturally happening events (i.e. 
temperature shock, rainfall inflow, hazardous events). Wang and Zhang [12] have done this type of study with activated sludge or pure culture in batch assays without membrane. They tested starvation, salinity, heavy metals, low $\mathrm{pH}$ and high temperature effects on SMP characteristics. Drews et al. [13] studied the role of various temperatures and nitrification rate on SMP elimination and rejection. In these works, there was no further insight into the specific modification produced on SMP components characteristics and their role in fouling. In that context, F/M ratio rapid changes (at 0.1 and $0.8 \mathrm{~kg}$ COD. $\mathrm{kg}_{\mathrm{MLVSS}}{ }^{-1} \cdot \mathrm{d}^{-1}$ ) were performed to simulate stressful conditions. Impacts in proteins and humic-like substances characteristics and modification in fouling establishment were assessed. With the same objectives, a last campaign was realized where SWW was replaced by real wastewater (RWW). MBR was working at SRT of $50 \mathrm{~d}$ at the same $\mathrm{F} / \mathrm{M}$ ratio of $0.2 \mathrm{~kg}$ COD.kgMLVss ${ }^{-1} \cdot \mathrm{d}^{-1}$ in order to compare obtained results with campaign realized with SWW and with the same operating conditions. At lab scale membrane fouling of MBR process studies are performed with SWW or RWW. This choice participates to the specification of biological medium characteristics (sludge flocs, EPS and SMP composition, concentrations and properties) [14] and could modify the conclusions obtained in term of membrane fouling structure and composition. Therefore this study could partly fill up the knowledge gap by performing two distinct experiments with substrate type as the only variable.

\section{Material and methods}

\subsection{MBR setup}

The 18 L external MBR (Polymem, France) was composed of a ceramic membrane (ultrafiltration, Novasep-Orelis, France) made with $\mathrm{ZrO}_{2}-\mathrm{TiO}_{2}$ (Figure 1). Membranes 
were characterized by a $150 \mathrm{kDa}$ cut off, a $0.02 \mathrm{~m}^{2}$ filtration area and an initial water permeability of $110 \mathrm{~L} \cdot \mathrm{h}^{-1} \cdot \mathrm{m}^{-2} \cdot \mathrm{bar}^{-1}$. A cooling system was used to maintain biomass at $25+/-1^{\circ} \mathrm{C}$. Transmembrane pressure (TMP) was monitored with manometers set at the inlet and outlet of the membrane module. The recirculation rate was maintained between 3.5-4 m.s ${ }^{-1}$ to limit membrane fouling. Biomass came from the same municipal wastewater treatment plant (WWTP) which is a submerged membrane bioreactor (Le Rousset, France, 12,000 inhabitant equivalents, $1800 \mathrm{~m}^{3} . \mathrm{d}^{-1}$, organic load 0.1 $\left.\mathrm{kg}_{\text {BOD5}} \cdot \mathrm{kg}_{\text {MLVSS }}{ }^{-1} \cdot \mathrm{d}^{-1}\right)$. The initial sludge mixed liquid volatile suspended solids (MLVSS) was around 6 g.L $\mathrm{L}^{-1}$ and corresponded to $80 \%$ of mixed liquid suspended solids (MLSS) concentration. Three campaigns were performed successively with the same MBR set-up as mentioned in figure 2. Campaigns 1 and 2 were realized with SWW at SRT of 50 and 20 d respectively. Sludge from municipal WWTP was sampled from the anoxic tank and then transported to the MBR pilot located in the laboratory without aeration (1 hour) for both experiments with SWW (campaigns 1 and 2). For campaign 3, MBR was moved in a container on the WWTP site to have available municipal RWW and sludge which was transferred from WWTP to pilot (20 min without aeration). Bioreactor aeration was performed with cycles $2 \mathrm{~h}$ with air/ $1 \mathrm{~h}$ without. During aeration periods a minimal dissolved oxygen concentration of 2 $\mathrm{mg}_{\mathrm{O} 2} \cdot \mathrm{L}^{-1}$ was supplied.

For each campaign, an acclimation period was realized to adapt sludge biomass to MBR pilot hydrodynamics conditions and SWW for campaigns 1 or 2. Durations of acclimation steps are presented in figure 2. Stable state was achieved as soon as accumulated sludge production versus time was linear. 
The main characteristics of MBR at stable state for the three campaigns are summarized in table 1. Further explanations on MBR characteristics, acclimation procedure and stable state determination are available in [15].

The constant flow rate mode was selected for MBR operations. As F/M ratios of chemical oxygen demand (COD) and $\mathrm{N}_{-} \mathrm{NH}^{+}{ }_{4}$ influence SMP production, these F/M ratios were maintained constant to allow comparison of SRT or substrate type influence on SMP characteristics for the three campaigns. Nevertheless as COD and N-NH+ ${ }_{4}^{+}$ concentrations were lower in RWW than in SWW, permeate flow of campaign 3 was voluntary increased from $0.75 \pm 0.02$ (campaigns 1 and 2) to $1.64 \pm 0.4 \mathrm{~L}^{-1}{ }^{-1}$ which induced a HRT decrease from 24 to $9 \mathrm{~h}$ for campaign 3 realized with RWW. This HRT variation was supposed to have no influence on SMP production as it was reported in [16].

To fix the SRT (d) at the desired value, the volume of waste sludge per day $\left({\mathrm{L} . \mathrm{d}^{-1}}^{-1}\right)$ named $V_{\text {waste }}$ was calculated with the following equation (Eq. (1)):

$$
\mathrm{V}_{\text {waste }}=\mathrm{V}_{\mathrm{R}} / \mathrm{SRT}
$$

With $\mathrm{V}_{\mathrm{R}}$ : volume of bioreactor (L).

MLSS and MLVSS measurements were regularly done with this daily wasted sludge. A part of this wasted AS (30 mL) was centrifuged $15 \mathrm{~min}$ at $16,000 \mathrm{~g}$ to isolate MBR supernatant from suspended solids. Removal rates of COD and $\mathrm{N}^{-\mathrm{NH}^{+}}{ }_{4}$ were calculated with concentration measurements in MBR feed and permeate. Nitrates were analyzed in bioreactor supernatant. COD, ammonium and nitrates measurements were done with 
colorimetric methods. Reagent kits from Aqua Lytic and Merk (Germany) were used respectively for COD and nitrates/ammonium concentrations determination.

\subsection{Substrate nature: SWW or RWW}

A balanced SWW $(\mathrm{C} / \mathrm{N} / \mathrm{P}$ ratio $=100 / 10 / 2)$ was prepared with mass ratios of 2.1 $\mathrm{C}_{6} \mathrm{H}_{12} \mathrm{O}_{6}$ (glucose), $1.0\left(\mathrm{NH}_{4}\right)_{2} \mathrm{SO}_{4}, 0.2 \mathrm{KH}_{2} \mathrm{PO}_{4}, 0.4 \mathrm{NaHCO}_{3}, 0.1 \mathrm{MgSO}_{4}$ and 0.02 $\mathrm{CaCl}_{2}$. During campaigns 1 and 2 with $\mathrm{SWW}, \mathrm{pH}$ was set at 7 with a $\mathrm{pH}$ controller delivering $\mathrm{NaHCO}_{3}$. SWW was prepared in a clean tank every 2 or 3 days. It was not sterilized allowing then bacterial development and SMP production. Therefore main components of SMP i.e. polysaccharides, proteins and humic-like substances were quantified as explained in part 2.3. Results are presented in table 1.

RWW was sampled after the different pre treatments in place on the WWTP of Le Rousset. An additional $200 \mu \mathrm{m}$ filtration was done before using it as feed for MBR pilot to avoid pump system default due to possible residual particles presence in pretreated RWW. Main characteristics of RWW are reported in table 2. RWW was stored in a tank at room temperature. During campaign $3 \mathrm{pH}$ regulation was not useful as bioreactor $\mathrm{pH}$ was stable at $7.0 \pm 0.1$.

\section{$2.3 \mathrm{~F} / \mathrm{M}$ ratio stress conditions}

F/M ratio variations on MBR feed were performed. These stress conditions were only applied at the end of campaign 1 (SWW, SRT of $50 \mathrm{~d}$ ) (Figure 2). The stress I was a F/M ratio decrease from 0.2 to $0.1 \mathrm{~kg}$ CoD. $\mathrm{kg}_{\text {MLVss }}{ }^{-1} \cdot \mathrm{d}^{-1}$ during one day. The stress II was a F/M ratio increase from 0.2 to $0.8 \mathrm{~kg}$ CoD. $\mathrm{kg}_{\mathrm{MLVss}}{ }^{-1} \cdot \mathrm{d}^{-1}$ during one day. For both F/M ratio changes mass ratio of $2.1 \mathrm{C}_{6} \mathrm{H}_{12} \mathrm{O}_{6}$ (glucose), $1.0\left(\mathrm{NH}_{4}\right)_{2} \mathrm{SO}_{4}, 0.2 \mathrm{KH}_{2} \mathrm{PO}_{4}, 0.4$ 
$\mathrm{NaHCO}_{3}, 0.1 \mathrm{MgSO}_{4}$ and $0.02 \mathrm{CaCl}_{2}$ was maintained. Between each F/M ratio variation, ten days were assessed as necessary to get stability of MBR process back. Steady state was assumed as sludge production and COD and ammonium removal rates were stable.

\subsection{SMP samples characteristics}

At steady state of the three campaigns AS was sampled to extract SMP by centrifugation ( $4000 \mathrm{~g}, 20 \mathrm{~min}, 4^{\circ} \mathrm{C}$ ). The number of SMP sampling events per campaign is accessible on figure 2. SMP content was also extracted from AS at the end of both stress times ( $24 \mathrm{~h}$ after the beginning of F/M ratio modification).

Polysaccharides [17], protein and humic-like substances [18] were quantified with colorimetric methods in substrate (Table 1), bioreactor supernatant and in permeate to evaluate the fraction of SMP due to bacterial metabolism and the fraction retained by the membrane after extraction by centrifugation $\left(4000 \mathrm{~g}, 20 \mathrm{~min}, 4^{\circ} \mathrm{C}\right)$; glucose (Sigma-Aldrich, 99.5\%), bovine serum albumin (Sigma-Aldrich, $98 \%$ ) and humic acids (Sigma-Aldrich) were used respectively as a standard for polysaccharides, proteins and humic-like substances contents. For each SMP sampling event analyses were done in triplicate.

Three dimensional Excitation Emission Matrix (3D-EEM) spectra of both substrates, typical MBR supernatant and permeates at stable state for the three campaigns and for SMP sampled during stress times were measured to select a couple of common Excitation/Emission wavelengths. 221/350 nm and 350/440 nm were respectively chosen for protein and humic-likes substances fluorescence detection after size exclusion chromatography (SEC) separation. Typical 3D-EEMs obtained are available 
as supplementary material (Figure S1). Deeper explanations of 3D-EEM method are contained in [19].

To assess apparent molecular weights (aMWs) distribution of protein and humic-like content of SMP in the different conditions, separation was carried out with a Merck Hitachi LA Chrom chromatograph equipped with a L7200 autosampler, a L7100 quaternary pump, a D7000 interface, fluorescence detector (L7485) and a diode array UV detector (L7455). Separation was performed with a high molecular weight (HMW) Amersham Biosciences column, the Agilent Bio SEC-300 A column and low molecular weight (LMW) Agilent Bio SEC $100 \AA$ A column having both high theoretical MW resolution range of 5-1250 $\mathrm{kDa}$ and 0.1 to $100 \mathrm{kDa}$ respectively. The total permeation volumes of the HMW and LMW columns were estimated to $11.5 \mathrm{~mL}$ and $10.3 \mathrm{~mL}$ respectively, using a sodium nitrate solution at $60 \mathrm{mg} \cdot \mathrm{mL}^{-1}$. A solution containing 150 $\mathrm{mM} \mathrm{NaCl}$ and $50 \mathrm{mM}$ phosphate buffer $\left(25 \mathrm{mM} \mathrm{Na}_{2} \mathrm{HPO}_{4}\right.$ and $\left.25 \mathrm{mM} \mathrm{NaH}_{2} \mathrm{PO}_{4}\right), \mathrm{pH}$ $7.0 \pm 0.1$ with constant flow rate of $1 \mathrm{~mL} \cdot \mathrm{min}^{-1}$ for both columns was used as mobile phase. $100 \mu \mathrm{L}$ of filtered samples $(0.2 \mu \mathrm{m})$ were injected for each analysis.

\subsection{Fouling resistance, permeability loss and TMP increase measurements}

Removable, irremovable and irreversible parts of fouling were assessed after the stable conditions (i.e. before stresses applications) for the three campaigns. The former can be removed by hydraulic cleaning and main contributor is the cake layer establishment. Irremovable fouling cannot be removed by simple hydraulic cleaning and requires drastic chemical cleaning. Irreversible fouling cannot be removed. To dissociate the different types of fouling, a succession of cleaning was applied. First distilled water cleaning was performed to remove removable fouling. After chemical cleanings (with 
$\mathrm{NaOH} 40 \mathrm{~g} \mathrm{~L}^{-1}$ followed by $\mathrm{HNO}_{3}$ concentrated at $68 \%$ ) were done. Between each cleaning step, the membrane permeability was measured. With the use of Eq. (2) below, hydraulic resistances due to each fouling types can be calculated and contribution of each fouling type can be obtained. Membrane hydraulic resistance was previously measured and is equal to $3 \cdot 3 \cdot 10^{12} \mathrm{~m}^{-1}$.

$$
L p=\frac{1}{\mu *(R m+R f)}
$$

With Lp: membrane permeability $\left(\mathrm{m}^{3} \mathrm{~m}^{-2} \mathrm{~s}^{-1} \mathrm{~Pa}^{-1}\right)$, Rf: fouling hydraulic resistance $\left(\mathrm{m}^{-}\right.$ $\left.{ }^{1}\right), \mathrm{Rm}$ : membrane hydraulic resistance $\left(\mathrm{m}^{-1}\right), \mu$ : dynamic viscosity of the permeate at 20 ${ }^{\circ} \mathrm{C}$ (Pa s). At stable state, for the three campaigns, relative permeability loss and TMP increase were measured respectively as ratio between variation of relative permeability or TMP on time. Both values were also calculated for each stress. Variations of relative permeability and TMP corresponded to the difference between values measured just before stress application and $24 \mathrm{~h}$ after.

\section{Results and discussion}

\subsection{SMP composition}

Campaigns 1 and 2 were realized at constant F/M ratio and SRT of 50 and $20 \mathrm{~d}$ respectively. At stable state MLSS content of both reactors were comparable at $9.1 \pm$ 1.2 g. $\mathrm{L}^{-1}$ for campaign 1 and $10.1 \pm 0.8 \mathrm{~g} . \mathrm{L}^{-1}$ for the second one (table 1$)$. Both bioreactors obtained efficient removals of COD and $\mathrm{N}_{-} \mathrm{NH}_{4}{ }^{+}$. Considering total SMP content presented in figure 3, it was double at SRT of $50 \mathrm{~d}$ with $17 \mathrm{mg}$.gMLVss ${ }^{-1}$. This is in contradiction with most of the literature published in this field [8-10, 20]. These opposed results came mainly from the way of operate MBR at different SRT. Typically, researches performed on the influence of SRT on SMP production in MBR system 
worked with a unique reactor and changed SRT progressively thanks to a decreasing amount of biomass purged. As less extraction of sludge was required to reach longer SRT, at constant nutrient content in the bioreactor feed, sludge concentration increased and then lower F/M ratio is supplied to biomass which is able to consume part of SMP content to counter substrate scarcity. Therefore SMP content observed in the previous cited studies were lower at higher SRT. In the present study SRT of 20 and $50 \mathrm{~d}$ were set in two different MBR working at the same F/M ratio and MLVSS concentration (table 1). It offers the advantage of a complete dissociation of F/M ratio and SRT and then SRT influence on SMP composition can be assessed. SMP content was higher at a SRT of $50 \mathrm{~d}$. In a previous study [15] performed in the same conditions, biomass activities were compared at SRT of 20 and 50 d. Higher heterotrophic activity was demonstrated at $50 \mathrm{~d}$ with a faster COD biodegradation than at $20 \mathrm{~d}$. As heterotrophic microorganisms present in AS are responsible for more than $92 \%$ of total SMP content [16], it seems likely that at longer SRT accumulation of SMP was observed.

The main component of SMP extracted from AS of MBR stabilized at $20 \mathrm{~d}$ was proteins with $63 \%$ of the total SMP content whereas it was polysaccharides at $50 \mathrm{~d}$ which represented $44 \%$ of the total SMP content. This higher content of polysaccharides measured from SMP content at SRT of $50 \mathrm{~d}$ might be due to their low biodegradation rate which could contribute to their accumulation in the bioreactor [21]. The total concentration of biopolymers from SWW was low (40 mg. $\left.\mathrm{L}^{-1}\right)$ (table 1) and represents only around $25 \%$ of the SMP concentration from RWW (155 mg.L $\left.{ }^{-1}\right)$. Polymers from RWW were mainly composed of humic-like substances $(65 \%)$ whereas SWW contained mainly proteins $(63 \%)$. As a part of RWW corresponds to rain water in contact with soil, it explains its high humic-like substances content. The 
polysaccharide concentration in SWW was voluntarily not shown. Indeed, as organic carbon used to prepare SWW was glucose, the main part of polysaccharide concentration observed came from this molecule. Polysaccharide content in SWW linked to micro-organisms metabolism was assumed to be low compared to glucose concentration. The main components of SMP extracted from biomass acclimated with SWW at SRT of $50 \mathrm{~d}$ were polysaccharides at $44 \%$ and proteins at $38 \%$. Protein concentration was higher in SMP extracted from bioreactor supernatant than from SWW at stable state. This result implies that bacterial metabolism was responsible for a soluble protein production in the MBR. Campaign 3 was realized with RWW. At stable state (SRT of $50 \mathrm{~d}$ ) a MLSS concentration of 7.6 \pm 0.9 g.L $\mathrm{L}^{-1}$ was maintained and good removal rates of COD and $\mathrm{N}-\mathrm{NH}_{4}{ }^{+}$were reached (table 1). The total SMP concentration observed in bioreactor fed with RWW decreased compared to the one measured in RWW. In SMP extracted from AS supernatant acclimated with RWW, proteins as humic-like substances concentrations decreased from 12 and $49 \mathrm{mg} . \mathrm{L}^{-1}$ respectively. As F/M ratios, SRT and MLSS concentrations were approximately the same in campaigns 1 and 3, influence of substrate nature on SMP characteristics can be discussed. Total concentrations of SMP extracted from biomasses fed with RWW or SWW were equivalent around $15 \mathrm{mg} \cdot \mathrm{g}_{\mathrm{MLVSS}}{ }^{-1}$. Nevertheless the composition of both SMP extracts were totally distinct. Polysaccharides were absent at stable state from SMP originating from AS fed with RWW whereas it was present at $44 \%$ for the AS coming from campaign 1. Polysaccharides content of RWW was low but stable during all the campaign 3 around $10 \mathrm{mg} . \mathrm{L}^{-1}$. During the first 20 days of campaign 3, polysaccharides were detected in SMP of AS at value around $4 \mathrm{mg} \cdot \mathrm{g}_{\mathrm{MLVSS}}{ }^{-1}$ and in the permeate with lower concentration $\left(0.3 \mathrm{mg} \cdot \mathrm{g}_{\mathrm{MLVSS}}{ }^{-1}\right)$. But for the next 50 days of campaign 3 , 
polysaccharides were not detected on SMP extracted from AS. It was assumed that polysaccharides from RWW may tightly adsorb on sludge flocs.

SMP samples extracted from AS during stress periods I (F/M ratio decrease) and II (F/M ratio increase) showed higher total amount of SMP of respectively 45 and 23 mg.gMLVss ${ }^{-1}$ compared to SMP amount observed during steady state $\left(17 \mathrm{mg} \cdot \mathrm{g}_{\text {MLVSS }}{ }^{-1}\right)$. This is in agreement with Sheng et al., [22] who mentioned that bacteria would excrete more microbial products under unfavorable conditions. During the F/M ratio decrease a drop of MLVSS concentration of $11 \%$ was observed and removal rates of ammonium and COD decreased respectively of 27 and $3 \%$. It is well accepted that SMP production increase with biomass concentration. As MLVSS decreased during stress I, this situation seems to have provoked a real stress on biomass. Furthermore, due to the high shear rate in external MBR, cellular content of dead cell and cell membrane fragments were released in the liquid medium explaining the higher content of SMP in the MBR supernatant during this first stress. The stress II has induced an augmentation of protein content in the bioreactor supernatant from 49 to $84 \mathrm{mg} . \mathrm{L}^{-1}$ whereas polysaccharides and humic-like substances content remained steady. This result was in agreement with a recent study realized with three sequencing batch reactors (SBR) working for 30 days with a constant F/M ratio which was growing between each SBR from 0.2 to $0.5 \mathrm{~kg}$ COD. $\operatorname{kg}_{\text {MLVSs}}{ }^{-1} \cdot \mathrm{d}^{-1}[11]$. With the highest F/M ratio tested, whereas polysaccharides content remained low and stable below $5 \mathrm{mg} . \mathrm{L}^{-1}$, proteins concentration was comprised between 17 and $32 \mathrm{mg} . \mathrm{L}^{-1}$. During this second stress, a $37 \%$ increase of MLVSS concentration was observed to reach 10.2 g.L $\mathrm{L}^{-1}$. High removal rate of COD was maintained with a small increase of $3 \%$ whereas $\mathrm{N}^{-\mathrm{NH}_{4}}{ }^{+}$elimination dropped of $48 \%$. Previous studies have already noticed the autotrophic biomass inhibition due to high 
content of ammonium in the feed [23]. One of the main metabolic pathways of glucose degradation is the glycolysis. Glucose biodegradation requires several enzymes to produce the energy needed to maintain bacterial catabolism. Therefore an increase in enzyme synthesis to biodegrade this excess of substrate could be a relevant explanation of this large amount of proteins released. Lobos et al. [24] have also noticed an increase of SMP protein content after an augmentation of F/M ratio.

\subsection{SMP retention and aMWs distribution}

SMP main components retention rates are presented in table 3. Polysaccharides retention rates were high at 87 and $100 \%$ for campaign 1 and 2 . These excellent polysaccharides retention rates were due to their high MW (> $100 \mathrm{kDa})$ measured in other studies $[9,21]$. Due to their low biodegradation rate [21] polysaccharides concentration was higher in AS supernatant of MBR working at a SRT of $50 \mathrm{~d}$ compared to values obtained at SRT of $20 \mathrm{~d}$. But with the increase of SRT, polysaccharides might be in a biodegraded state more advanced i.e. lower MW which could explain a decrease of polysaccharides retention with SRT augmentation.

During campaigns 1 and 2 realized with SWW, protein content from SMP extracted from AS exhibited higher retention rate during campaign 1 (93\%) than for campaign 2 (69\%). aMWs of SMP protein content extracted from bioreactors of campaigns 1 and 2 are presented in table 4. aMWs of protein found in permeate were highlighted in bold type in the same table. For both campaigns, SMP protein content extracted from bioreactors exhibited aMWs ranging from aMWs higher than $670 \mathrm{kDa}$ to under than 0.5 $\mathrm{kDa}$. Proteins from SMP content of both bioreactors have shown larger aMWs (equal or larger than $40 \mathrm{kDa}$ ) than the one observed for protein content of SWW. These protein 
compounds were aggregated with the other organic foulants present in bioreactors and are called biopolymer clusters. Main components of these biopolymers are polysaccharides [4]. Sun et al. [25] pointed out that MBR is an enclosed system that concentrates organic foulants in bulk solution causing aggregation of SMP to biopolymers clusters causing cake deposition and severe membrane fouling. Literature referenced such compounds and considers them as the most fouling fraction of SMP [26-28].

aMW of protein-like substances at SRT of $20 \mathrm{~d}$ present less small molecules $(<1 \mathrm{kDa})$ than at $50 \mathrm{~d}$. A part of compounds with high aMW (>670, 300 and $40 \mathrm{kDa}$ ) might be biodegraded on smaller compounds as SRT increases. In their study of SMP characteristics at various SRT in ceramic MBR, Shin and Kang [29] confirmed that when SRT increases from 40 to $80 \mathrm{~d}$, proportion of small molecules with aMW less than $1 \mathrm{kDa}$ is higher and the content of SMP of size between 30-100 kDa and superior than $100 \mathrm{kDa}$ decreases due to SMP bacterial degradation. Nevertheless higher protein retention was observed during campaign 1 . With their large MW and their gelling properties, polysaccharides highly take part to membrane fouling with a gel layer formation [21]. As polysaccharides content was higher in SMP from campaign 1 than 2 (figure 3), gel layer could be thicker. Chen et al. [6] proved that agar gel layer attached to the membrane of their MBR system presented higher filtration resistance when agar gel layer was thicker. Therefore, proteins with smaller aMWs of the campaign 1 could be embedded in the gel layer and could participate to porosity reduction of this gel layer.

Protein content of SMP from campaign 3 realized with RWW was poorly retained (13 $\%$ ). aMWs distribution of SMP proteins from campaign 3 presented similar sizes with 
aMWs distribution of proteins from SMP of campaign 1 and 2. Biopolymer clusters $(\mathrm{aMW}>670 \mathrm{kDa})$, one fraction at $30 \mathrm{kDa}$ and numerous fractions with aMWs equal or smaller than $5 \mathrm{kDa}$ were visible. The low protein retention on campaign 3 indicates that fractions with small sizes $(<5 \mathrm{kDa})$ were predominant in the bioreactor.

A rapid analysis of aMWs of proteins from permeates of the three campaigns allows to say that $150 \mathrm{kDa}$ membrane was able to retain proteins five times smaller than its cut off. Permeates of all samples mentioned in normal conditions in table 4 were constituted of protein-like substances with aMW less than $5 \mathrm{kDa}$. This result confirms the one found by Jang et al. [30] who noted that $81 \%$ of proteins and polysaccharides of MBR permeate filtered with $0.4 \mu \mathrm{m}$ membrane had aMW less than $1 \mathrm{kDa}$.

Substrate type seems to have no influence on aMWs distribution of humic-like substances as size distribution was narrow between 1 and $5 \mathrm{kDa}$ for both campaigns 1 and 3. Nevertheless, SRT could have an influence on humic-like substances size repartition as only fractions with lower aMWs than $1 \mathrm{kDa}$ were observed. At longer SRT, a rearrangement with other organic molecules could explain the presence of humic-like substances of higher aMWs. These compounds were poorly retained (lower than $50 \%$ for the three campaigns). Humic-like substances can contribute to membrane fouling by adsorption phenomenon on/into membrane pores [31]. Johir et al. [27] announced that after bio cluster, humic substances are the major membrane foulants. Polysaccharides retention rates seem to be not influenced by stresses performed with F/M ratio modifications as for both applied stresses retentions were equal or higher than $90 \%$. 
Protein retention rate measured after the second stress was high (99\%) and in the same range than the one obtained at stable state of the campaign 1 . In that case, fractions with aMWs of 300 and $40 \mathrm{kDa}$ were absent from aMWs distribution of SMP proteins. Only 1 $\%$ of SMP proteins were found in permeate with aMWs lower than $1 \mathrm{kDa}$. This result implies that SMP protein during stress II are mainly associated to the bio polymer structures $(>670 \mathrm{kDa})$. After the application of stress I, a decrease of SMP protein retention rate was measured (84\%). New fractions with aMWs of 400, 200 and $20 \mathrm{kDa}$ appeared. According to Wang and Zhang [12] AS suffering from stressful conditions are induced to produce more low MW components of SMP during the utilization of substrate. As a biomass drop was obtained during that stressful conditions (11\%), these compounds could be part of biomass cell lysis. They could also be the biodegradation products of SMP with higher aMWs.

Application of stresses I and II implied strong modifications of humic-like substances retention rates. This retention was improved after stress I until $75 \%$ whereas a higher concentration of humic like substances was found in permeate after stress II provoking their negative retention (-53\%). During second stress, protein and polysaccharide parts of SMP are extremely well retained. Both components are implied on membrane fouling and could have formed a fouling layer with high porosity due to their high aMWs. This hypothesis could explain that humic-like substances during stress II were not retained. A modification of aMWs distribution of humic-like substances was also visible and could have contributed to the lower rejection rate observed. At stable state of campaign 1, humic-like substances present a bimodal repartition between 1 and $5 \mathrm{kDa}$. After stress II a multiplication of fractions with low aMWs $(<1 \mathrm{kDa})$ appeared. 
After stress I, aMWs of humic-like substances were distributed in the same range than after stress II but their rejection rate was improved. A modification of the fouling layer structure may explain this variation. Proteins were less retained and fractions with aMWs of 200 and $20 \mathrm{kDa}$ appeared. Porosity of fouling layer may have been reduced allowing better retention of humic-like substances.

\subsection{Influence of SMP in membrane fouling}

Relative permeability, TMP and permeate flux at $20{ }^{\circ} \mathrm{C}$ evolution with time for the three campaigns are presented in figure 4. MBRs were operated at constant permeate flow rate of 0.76 and $0.75 \mathrm{~L} . \mathrm{h}^{-1}$ for campaigns 1 and 2 respectively and $1.64 \mathrm{~L} \cdot \mathrm{h}^{-1}$ for campaign 3 (table 1). To maintain these permeate flow rates, TMP was progressively increased during each campaign. Table 5 listed values of TMP increase and permeability loss at stable state as membrane fouling resistance repartition (removable, irremovable, irreversible percentages) for the three campaigns. For campaigns 1 and 2, MBRs were operated without chemical cleaning during the entire experiment and TMP jump was not reached. SMP are mainly involved in membrane fouling during initial stage (i.e. before the TMP jump) [5]. During both campaigns MLSS concentrations were relatively similar at $9.1 \pm 1.2$ (campaign 1 ) and $10.1 \pm 0.8$ (campaign 2 ) g.L $\mathrm{L}^{-1}$. As the only distinction between MBR bulk solutions of campaigns 1 and 2 was SMP characteristics variations provoked by SRT change, differences observed in term of fouling repartition, TMP increase and permeability loss could be attributed to these SMP modifications. Permeability loss at stable state was the same for both campaigns, but TMP increase was slightly faster during campaign $1\left(0.046 \mathrm{kPa} \cdot \mathrm{h}^{-1}\right)$ than during campaign $2\left(0.015 \mathrm{kPa} \cdot \mathrm{h}^{-1}\right)$. A more pronounced mass transfer limitation corresponded well with this higher TMP increase at a SRT of $50 \mathrm{~d}$. A ticker fouling layer composed 
of polysaccharides with embedded small proteins on the membrane surface and in pores at SRT of $50 \mathrm{~d}$ could confirm this result. For both experiments, main part of fouling was irremovable. The irremovable part of fouling was of $90 \%$ for campaign 1 and $85 \%$ for campaign 2. Usually, the main part of fouling in MBR (80\%) is removable and could be attributed to a cake layer formation [3]. Most of MBRs in literature operated with organic membranes organized as hollow fibers or flat sheet membrane modules submerged in bulk solution. This type of systems works under lower recirculation rates than the ones applied with ceramic modules allowing fouling establishment mainly as a cake layer [32-33]. The irremovable fouling is attributed to pore blocking. The slight higher irremovable part of fouling observed at SRT of $50 \mathrm{~d}$ may be attributed to the larger proportion of proteins with small aMWs $(<1 \mathrm{kDa})$. For campaign 3 realized with RWW, two rapid loss of relative permeability were visible around day 10 and 40 . These relative permeability drops corresponded with the TMP jump which was reached to maintain constant permeate flux around $80 \mathrm{~L} \cdot \mathrm{h}^{-1} \cdot \mathrm{m}^{-2}$ during acclimation phase. During both TMP jump, severe fouling was noted and was mainly due to increase of MLSS concentration higher than 10 g. $\mathrm{L}^{-1}$. At stable state permeate flux was maintained around $70 \mathrm{~L} \cdot \mathrm{h}^{-1} \cdot \mathrm{m}^{-2}$ and TMP increase and permeability loss were low and in the same range than values of campaign 2 . The fouling was at $94 \%$ irremovable. As no polysaccharides were present in SMP of campaign 3, the cake layer contribution to membrane fouling was low (4\%). The poorly retained humic-like substances and proteins of small sizes mainly contributed to the membrane pore blocking. The stress I caused a drastic fouling as TMP increase and permeability loss were around 20 times higher than during stable state of campaign 1 . The more compact fouling layer mentioned in part 3.2 could have provoked higher mass transfer limitation in that case. 


\section{Conclusions}

Proteins and humic-like substances content of SMP were characterized and their role in membrane fouling layer was determined. With the increase of SRT from 20 to $50 \mathrm{~d}$ a thicker layer of fouling occured. SRT of $20 \mathrm{~d}$ was preferable to limit membrane fouling propensity. Filtration performances were severely affected by F/M ratio decrease and the implementation of a compact fouling layer. Substrate choice for lab scale MBR operation do not affect main sizes of proteins and humic-like substances but fouling layers were specific depending on substrate used.

\section{References}

[1] M. Yang, D. Yu, M. Liu, L. Zheng, X. Zheng, Y. Wei, et al., Optimization of MBR hydrodynamics for cake layer fouling control through CFD simulation and RSM design, Biores. Technol. 227 (2017) 102-111.

[2] H. Hong, M. Zhang, Y. He, J. Chen, H. Lin, Fouling mechanisms of gel layer in a submerged membrane bioreactor, Biores. Technol. 166 (2014) 295-302.

[3] F. Meng, S.R. Chae, A. Drews, M. Kraume, H.S. Shin, F. Yang, Recent advances in membrane bioreactors (MBRs): Membrane fouling and membrane material, Water Res. 43 (2009) 1489-1512.

[4] F. Meng, S. Zhang, Y. Oh, Z. Zhou, H.S. Shin, S.R. Chae, Fouling in membrane bioreactors: An updated review, Water Res. 114 (2017) 151-180.

[5] Z. Zhou, F. Meng, X. He, S.R. Chae, Y. An, X. Jia, Metaproteomic analysis of biocake proteins to understand membrane fouling in a submerged membrane bioreactor, Environ. Sci. Technol. 49 (2015) 1068-1077. 
[6] J. Chen, M. Zhang, F. Li, L. Qian, H. Lin, L. Yang, et al., Membrane fouling in a membrane bioreactor: High filtration resistance of gel layer and its underlying mechanism, Water Res. 102 (2016) 82-89.

[7] C.Y.Y. Tang, T.H. Chong, A.G. Fane, Colloidal interactions and fouling of NF and RO membranes: A review, Adv. Colloid Interface Sci. 164 (2011) 126-143.

[8] M. Esparza-Soto, S. Nunez-Hernandez, C. Fall C, Spectrometric characterization of effluent organic matter of a sequencing batch reactor operated at three sludge retention Times, Water Res. 4-5 (2011) 6555-6563.

[9] S. Rosenberger, C. Laabs, B. Lesjean, R. Gnissr, G. Amy, M. Jekel, et al., Impact of colloidal and soluble organic material on membranes performances in membrane bioreactors for municipal wastewater treatment, Water Res. 40 (2006) 710-720.

[10] S. Liang, C. Liu, L. Song, Soluble microbial products in membrane bioreactor operation: Behaviors, characteristics, and fouling potential, Water Res. 41 (2007) 95101.

[11] E. Ferrer-Polonio, K. White, J.A. Mendoza-Roca, A. Bes-Piá, The role of the operating parameters of SBR systems on the SMP production and on membrane fouling reduction, J. Environ. Manag. 228 (2018) 205-212.

[12] Z.P. Wang, T. Zhang, Characterization of soluble microbial products (SMP) under stressful conditions, Water Res. 44 (2010) 5499-5509.

[13] A. Drews, J. Mante, V. Iversen, M. Vocks, B. Lesjean, M. Kraume, Impact of ambient conditions on SMP elimination and rejection in MBRs, Water Res. 41 (2007), $3850-3858$.

[14] E. McAdam, S. Judd, E. Cartmell, B. Jefferson, Influence of substrate on 
fouling in anoxic immersed membrane bioreactors, Water Res. 41 (2007) 3859-3867.

[15] M. Villain, B. Marrot, Influence of sludge retention time at constant food to microorganisms ratio on membrane bioreactor performances under stable and unstable state conditions, Biores. Technol. 128 (2013) 134-144.

[16] W.M. Xie, B.J. Ni, T. Seviour, G.P. Sheng, H.Q. Yu, Characterization of autotrophic and heterotrophic soluble microbial product (SMP) fractions from activated sludge, water res. 46 (2012) 6210-6217.

[17] M. Dubois, K.A. Gilles, J.K. Hamilton, P.A. Rebers, F. Smith, Colorimetric method for determination of sugars and related substances, Anal. Chem. 28 (1956) 350356.

[18] B. Frolund, T. Griebe, P.H. Nielsen, Enzymatic activity in the activated-sludge floc matrix, Appl. Microbiol. Biotechnol. 43 (1995) 755-761.

[19] M. Villain, I. Bourven, G. Guibaud, B. Marrot, Impact of synthetic or real urban wastewater on membrane bioreactor (MBR) performances and membrane fouling under stable conditions, Biores. Technol. 155 (2014) 235-244.

[20] W. Lee, S. Kang, H. Shin, Sludge characteristics and their contribution to microfiltration in submerged membrane bioreactors, J. Membr. Sci. 216 (2003) 217227.

[21] F. Meng, Z. Zhou, B.J. Ni, X. Zheng, G. Huang, X. Jia, et al., Characterization of the size-fractionated biomacromolecules: Tracking their role and fate in a membrane bioreactor. Water Res. 45 (2011) 4661-4671.

[22] G.P. Sheng, H.Q. Yu, X.Y. Li, Extracellular polymeric substances (EPS) of microbial aggregates in biological wastewater treatment systems: A review. Biotechnol. Adv. 28 (2010) 882-894. 
[23] J. Gagnaire, Couplage de procédés appliqués au traitement d' un effluent decompostage. Thèse de doctorat, 2010, M2P2, Aix-Marseille.

[24] J. Lobos, C. Wisniewski, M. Heran, A. Grasmick, Effects of starvation conditions on biomass behaviour for minimization of sludge production in membrane bioreactors, Water Sci. Technol. 51 (2005) 35-44.

[25] F. Sun, X. Wang, X. Li, Change in the fouling propensity of sludge membrane bioreactors in relation to the accumulation of biopolymer clusters, Biores. Technol. 102 (2011) 4718-4725.

[26] M. Yao, B. Ladewig, K. Zhang, Identification of the change of soluble microbial products on membrane fouling in membrane bioreactor (MBR), Desalination. 278 (2011) 126-131.

[27] M.A.H. Johir, S. Vigneswaran, A. Sathasivan, J. Kandasamy, C.Y. Chang, Effect of organic loading rate on organic matter and foulant characteristics in membrane bioreactor, Biores. Technol. 113 (2012) 154-160.

[28] Y.X. Shen, X. Kang, P. Liang, J.Y. Sun, S.J. Sai, X. Huang, Characterization of soluble microbial products in10 large-scale membrane bioreactors for municipal wastewater treatment in China,. J. Memb. Sci. 415-416 (2012) 336-345.

[29] H.S. Shin, S.T. Kang, Characteristics and fates of soluble microbial products in ceramic membrane bioreactor at various sludge retention times, Water Res. 37 (2003) 121-127.

[30] N. Jang, X. Ren, G. Kim, C. Ahn, J. Cho, I.N. Kim, Characteristics of soluble microbial products and extracellular polymeric substances in the membrane bioreactor for water reuse, Desalination. 202 (2007) 90-98. 
[31] L. Shen, Y. Zhou, B. Mahendran, D.M. Bagley, S.N. Liss. Membrane fouling in a fermentative hydrogen producing membrane bioreactor at different organic loading rates, J. Membr. Sci. 360 (2010) 226-233.

[32] Y. Liu, H. Liu, L. Cui, K. Zhang, K., The ratio of food-to microorganism (F/M) on membrane fouling of anaerobic membrane bioreactors treating low-strength wastewater, Desalination 297 (2012) 97-103.

[33] M. Zhang, W. Peng, J. Chen, Y. He, L. Ding, A. Wang, et al., A new insight into membrane fouling mechanism in submerged membrane bioreactor: Osmotic pressure during cake layer filtration, water res. 47 (2013) 2777-2786. 


\section{Tables and figures legends}

Figure 1. Experimental set up of MBR

Figure 2. MBR campaigns characteristics and corresponding SMP sampling schedule

Figure 3. Influence of SRT (20 or $50 \mathrm{~d}$ ), substrate type (SWW or RWW) and stress period (stress I: F/M ratio decrease and stress II: F/M ratio increase) on SMP composition in MBR bioreactor supernatant and permeate

Figure 4. Membrane relative permeability, TMP and permeate flux at $20^{\circ} \mathrm{C}$ for MBR working with SWW at a SRT of $50 \mathrm{~d}$ (A and D), with SWW at SRT of $20 \mathrm{~d}$ (B and E) and with RWW at SRT of $50 \mathrm{~d}(\mathrm{C}$ and F)

Figure S1. 3D-EEM of (A) RWW, (B) MBR bioreactor supernatant (RWW ; SRT=50

d) (C) corresponding permeate, (D) SWW, (E) MBR bioreactor supernatant (SWW ; SRT=50 d), (F) corresponding permeate, (G) SMP extracted during stress period I and (H) II

Table 1. MBR operating conditions, substrates biochemical characteristics, COD and N$\mathrm{NH}_{4}{ }^{+}$removal rates of lab scale MBR at stable state for the three campaigns

Table 2. RWW main characteristics

Table 3. Influence of SRT (20 or 50 d), substrate type (SWW or RWW) and stress period (stress I: F/M ratio decrease and stress II: F/M ratio increase) on SMP retention rate

Table 4. aMW determined for protein and humic-like substances content of substrates, MBR supernatant and permeate in the different conditions tested 
Table 5. TMP increase and permeability loss of MBR process in the different conditions tested 
Figure 1

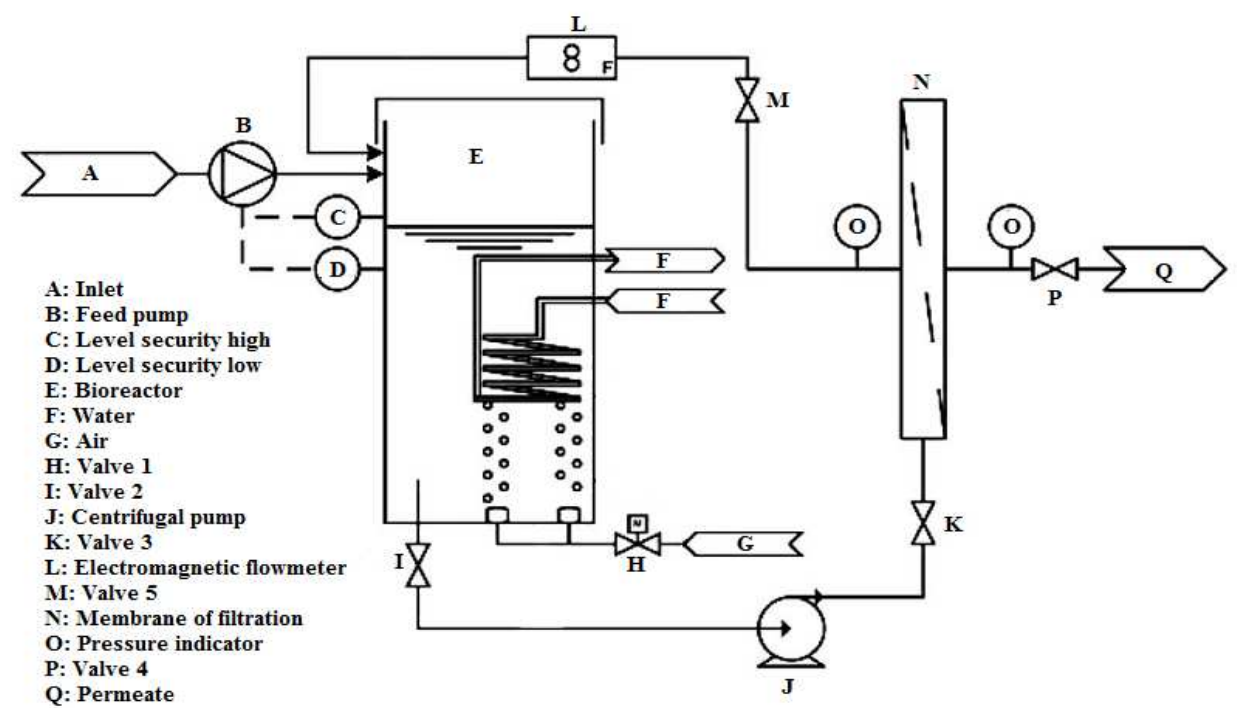




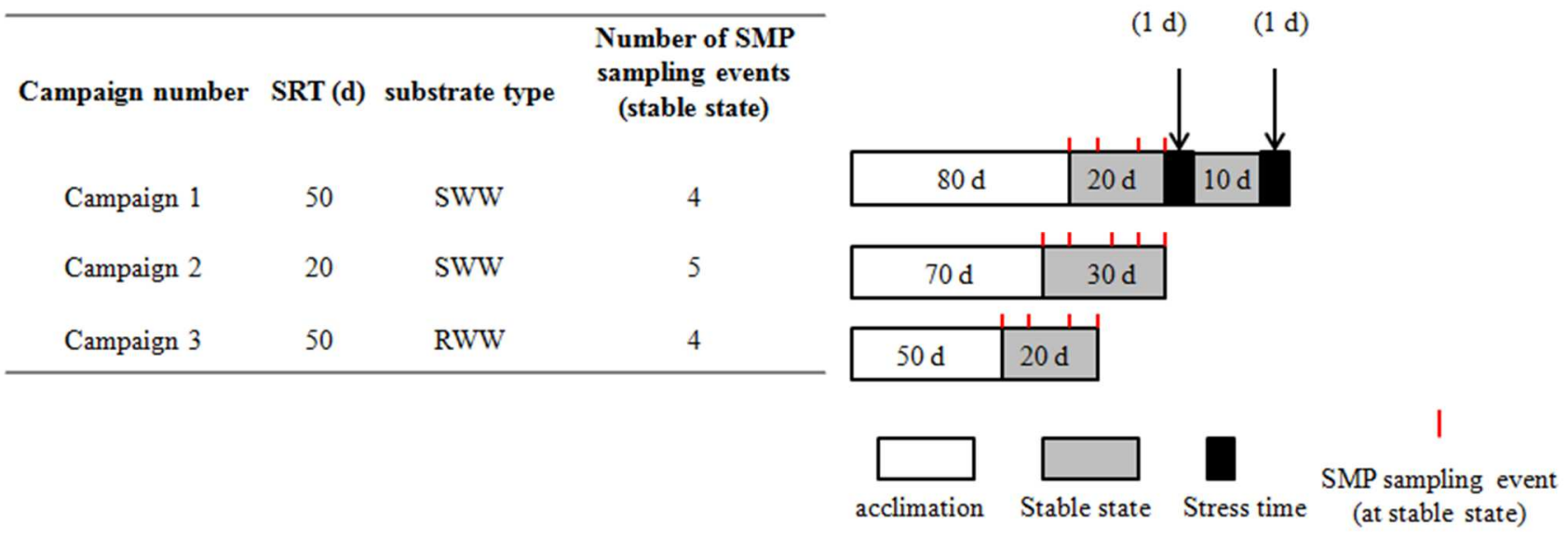

Figure 2 


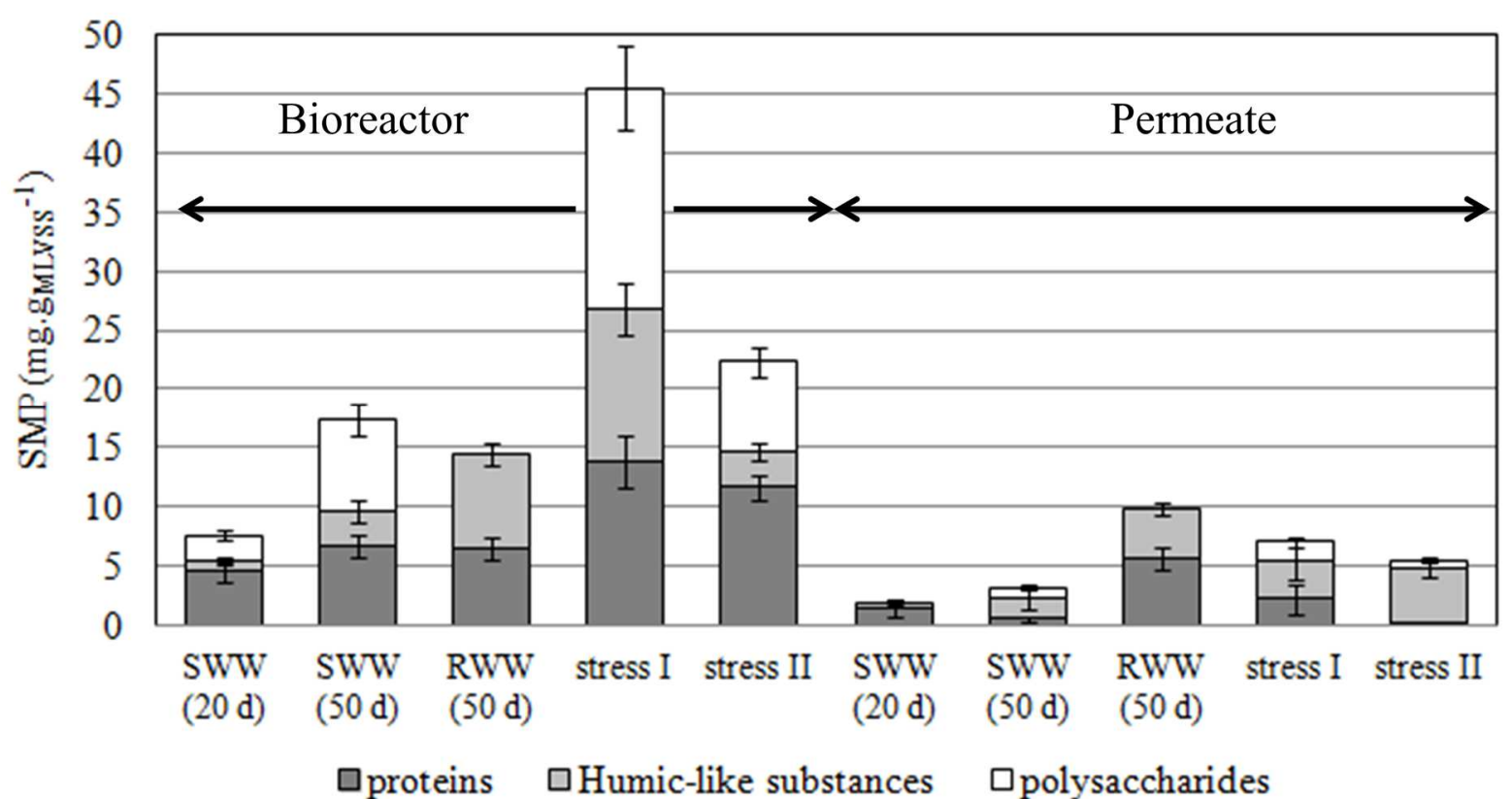

Figure 3 
(A)

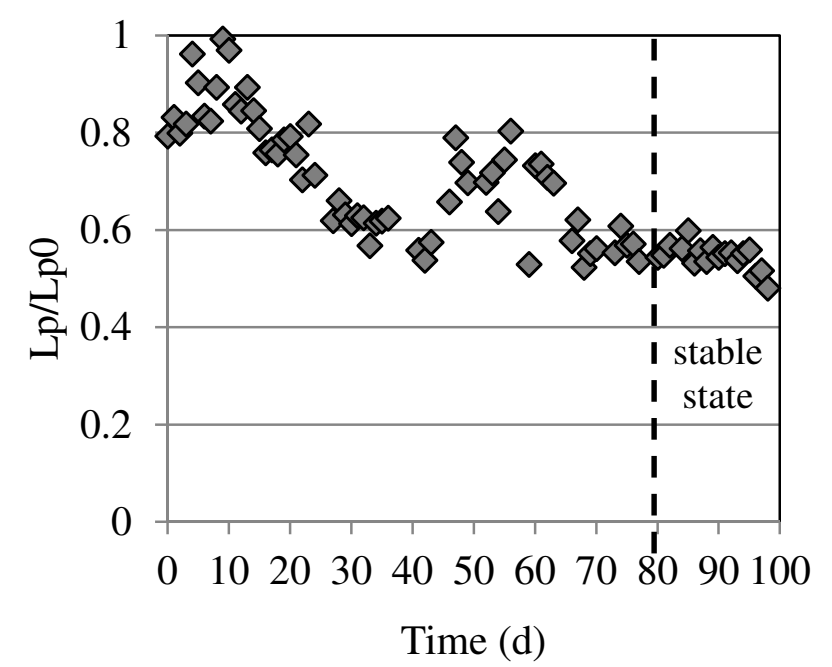

(D)

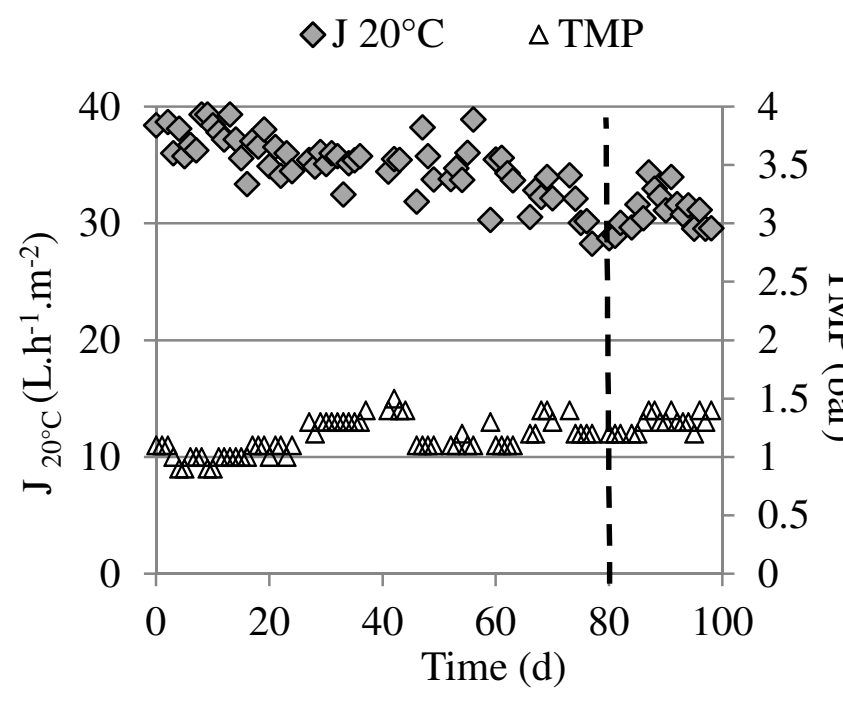

(B)

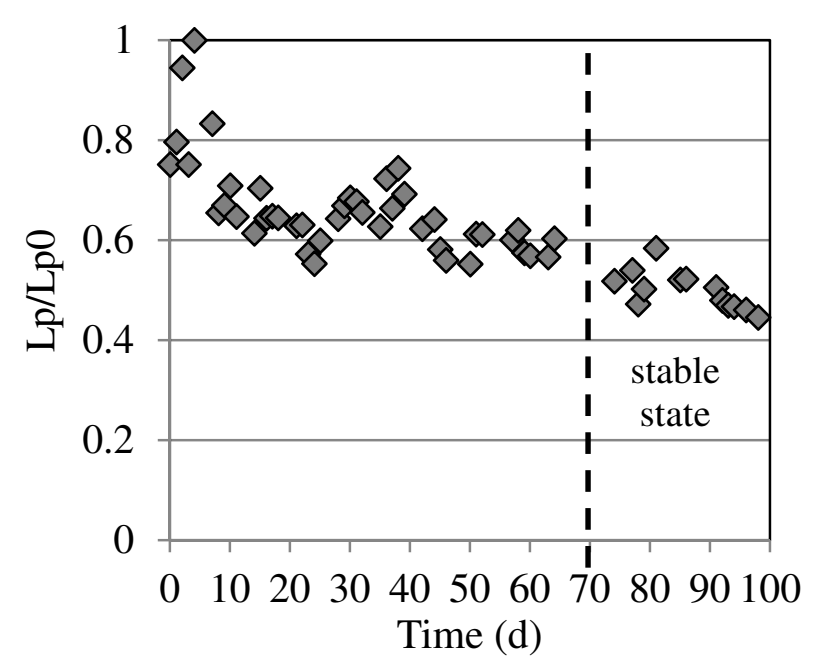

(E)

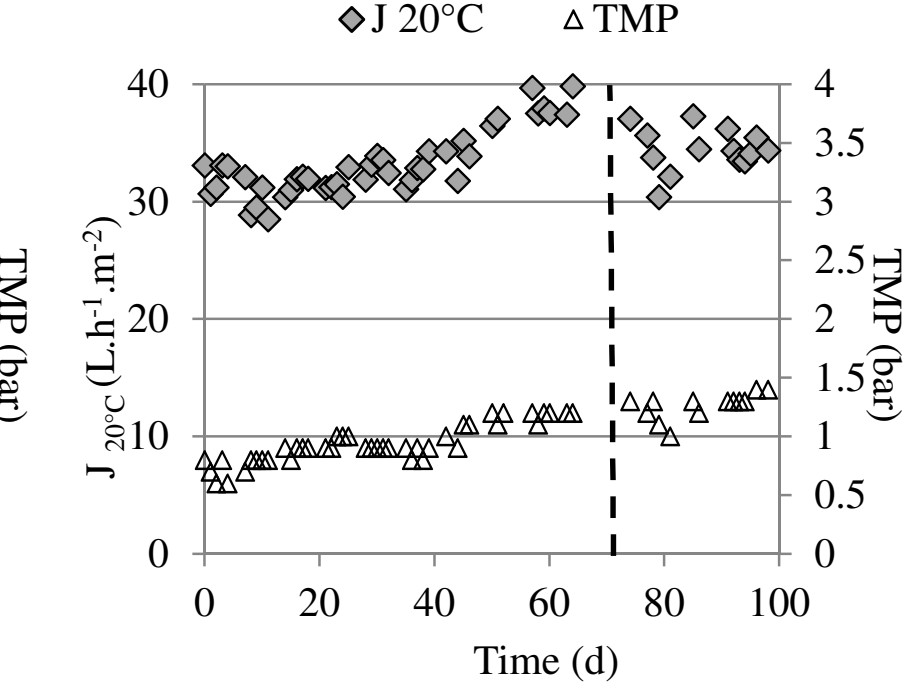

(C)

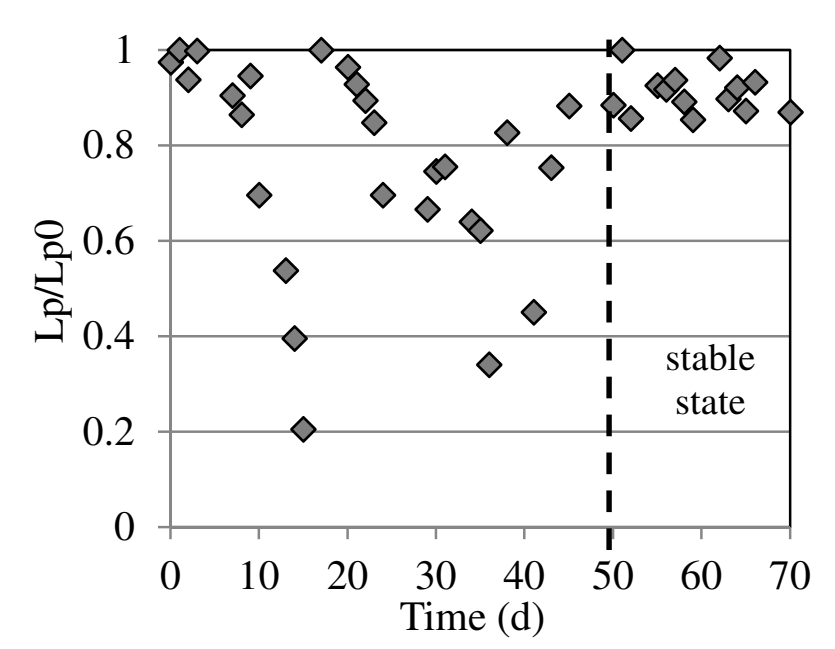

(F)

$\diamond \mathrm{J} 20^{\circ} \mathrm{C} \quad \triangle \mathrm{TMP}$

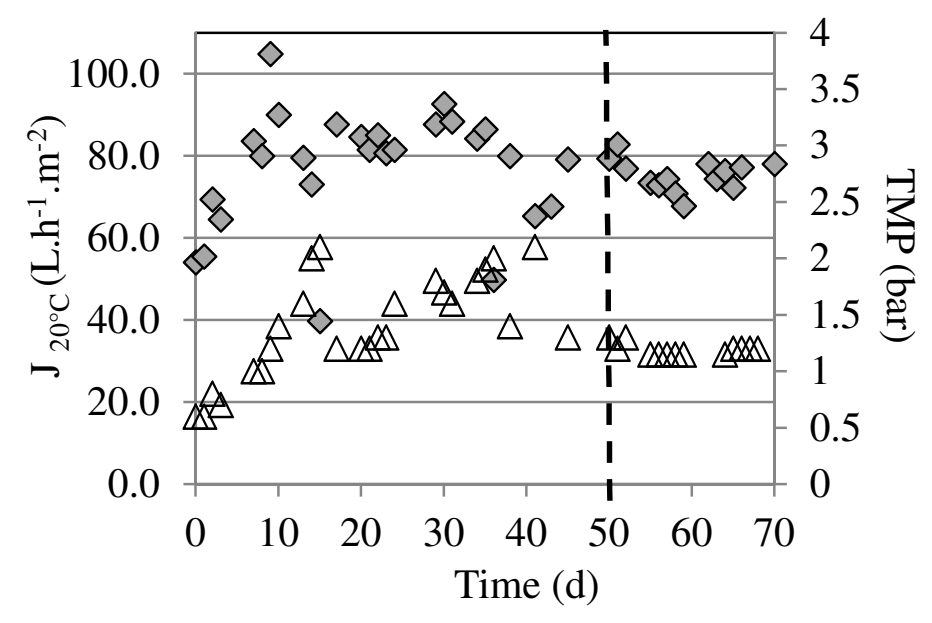

Figure 4 


\begin{tabular}{|c|c|c|c|c|}
\hline & Table 1 & Campaign 1 & Campaign 2 & Campaign 3 \\
\hline \multirow{7}{*}{ 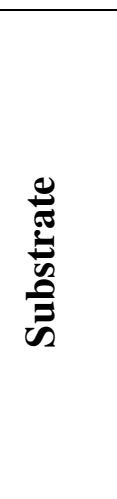 } & Substrate type & SWW & SWW & RWW \\
\hline & $\mathbf{N}-\mathrm{NH}^{+}{ }_{4} \mathbf{F} / \mathbf{M}$ (food to microorganisms ratio) $\left({\mathrm{kg} \mathrm{N}-\mathrm{NH}^{+}}^{+} \cdot \mathrm{kg}_{\mathrm{MLVSs}}{ }^{-1} \cdot \mathrm{d}^{-1}\right)$ & $0.016 \pm 0.003$ & $0.015 \pm 0.001$ & $0.014 \pm 0.008$ \\
\hline & COD F/M $\quad\left(\mathrm{kg} \mathrm{COD}_{\mathrm{kg}} \cdot \mathrm{kg}_{\mathrm{MLVS}}{ }^{-1} \cdot \mathrm{d}^{-1}\right)$ & $0.21 \pm 0.02$ & $0.23 \pm 0.02$ & $0.19 \pm 0.02$ \\
\hline & Biochemical composition of substrate (mg. $\left.\mathrm{L}^{-1}\right)$ & & & \\
\hline & Proteins & $35 \pm 4$ & $43 \pm 7$ & $48 \pm 20$ \\
\hline & Polysaccharides & - & - & $10 \pm 5$ \\
\hline & Humic-like substances & $5 \pm 1$ & $7 \pm 2$ & $97 \pm 31$ \\
\hline \multirow{3}{*}{ 总 } & Sludge retention time (SRT) (d) & 50 & 20 & 50 \\
\hline & Mixed liquor suspended solids (MLSS) $\left(\mathrm{g}_{\left.\mathrm{MLSS} . \mathrm{L}^{-1}\right)}\right.$ & $9.1 \pm 1.2$ & $10.1 \pm 0.8$ & $7.6 \pm 0.9$ \\
\hline & Mixed liquor volatile suspended solids (MLVSS) (\%) & $82 \pm 1$ & $81 \pm 1$ & $78 \pm 2$ \\
\hline \multirow{6}{*}{ : } & Volume (L) & 18 & 18 & 15 \\
\hline & Hydraulic retention time (HRT) (h) & $24 \pm 1$ & $24 \pm 1$ & $9 \pm 3$ \\
\hline & Permeate flow $\left(\mathrm{L} \cdot \mathrm{h}^{-1}\right)$ & $0.76 \pm 0.02$ & $0.75 \pm 0.02$ & $1.64 \pm 0.4$ \\
\hline & Permeate flux at $20^{\circ} \mathrm{C}\left(\mathrm{L} \cdot \mathrm{h}^{-1} \cdot \mathrm{m}^{-2}\right)$ & $32.6 \pm 2.5$ & $33.8 \pm 2.5$ & $70.1 \pm 16$ \\
\hline & Recirculation rate $\left(\mathrm{m} \cdot \mathrm{s}^{-1}\right)$ & $3.5-4$ & $3.5-4$ & $3.5-4$ \\
\hline & Transmembrane pressure (TMP) (bar) & $1.3 \pm 0.1$ & $1.3 \pm 0.1$ & $1.2 \pm 0.2$ \\
\hline \multirow{2}{*}{ 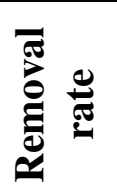 } & $\operatorname{COD}(\%)$ & $96 \pm 3$ & $99 \pm 1$ & $97 \pm 3$ \\
\hline & $\mathbf{N}-\mathrm{NH}^{+}{ }_{4}(\%)$ & $78 \pm 4$ & $71 \pm 3$ & $99 \pm 1$ \\
\hline
\end{tabular}




\begin{tabular}{|c|c|c|c|c|}
\hline Parameters & Month 1 & Month 2 & Month 3 & Month 4 \\
\hline $\operatorname{MLSS}\left(\mathbf{m g . L} \mathbf{L}^{-1}\right)$ & $270 \pm 20$ & $283 \pm 35$ & $323 \pm 64$ & $284 \pm 42$ \\
\hline COD (mg.L-1) & $665 \pm 78$ & $767 \pm 212$ & $626 \pm 14$ & $720 \pm 95$ \\
\hline BOD5 (mg.L $\left.\mathbf{L}^{-1}\right)$ & $255 \pm 35$ & $279 \pm 92$ & $157 \pm 85$ & $282 \pm 28$ \\
\hline $\mathrm{N}-\mathrm{NH}_{4}{ }^{+}\left(\mathbf{m g . L} \mathbf{L}^{-1}\right)$ & $51 \pm 4$ & $44 \pm 11$ & $29 \pm 15$ & $52 \pm 4$ \\
\hline Global ammonium (mg.L $\left.{ }^{-1}\right)$ & $67 \pm 6$ & $62 \pm 15$ & $47 \pm 12$ & $71 \pm 4$ \\
\hline Total phosphorous (mg.L ${ }^{-1}$ ) & $8 \pm 1$ & $7 \pm 1$ & $5 \pm 2$ & $8 \pm 1$ \\
\hline
\end{tabular}

Table 2 


\begin{tabular}{cccccccc}
\hline conditions & $\begin{array}{c}\text { Campaign } \\
\text { number }\end{array}$ & $\begin{array}{c}\text { Substrate } \\
\text { type }\end{array}$ & $\begin{array}{c}\text { SRT } \\
\text { (d) }\end{array}$ & Proteins & Polysaccharides & $\begin{array}{c}\text { Humic-like } \\
\text { substances }\end{array}$ & Total \\
\hline & 1 & SWW & 50 & $93 \pm 4$ & $87 \pm 2$ & $41 \pm 1$ & $82 \pm 2$ \\
Stable state & 2 & SWW & 20 & $69 \pm 2$ & $100 \pm 5$ & $44 \pm 2$ & $75 \pm 3$ \\
& 3 & RWW & 50 & $13 \pm 1$ & - & $47 \pm 3$ & $32 \pm 1$ \\
Stress I (F/M ratio decrease) & 1 & SWW & 50 & $84 \pm 5$ & $92 \pm 3$ & $75 \pm 4$ & $85 \pm 3$ \\
Stress II (F/M ratio increase) & 1 & SWW & 50 & $99 \pm 3$ & $90 \pm 5$ & $-53 \pm 4$ & $75 \pm 3$ \\
\hline
\end{tabular}

Table 3 


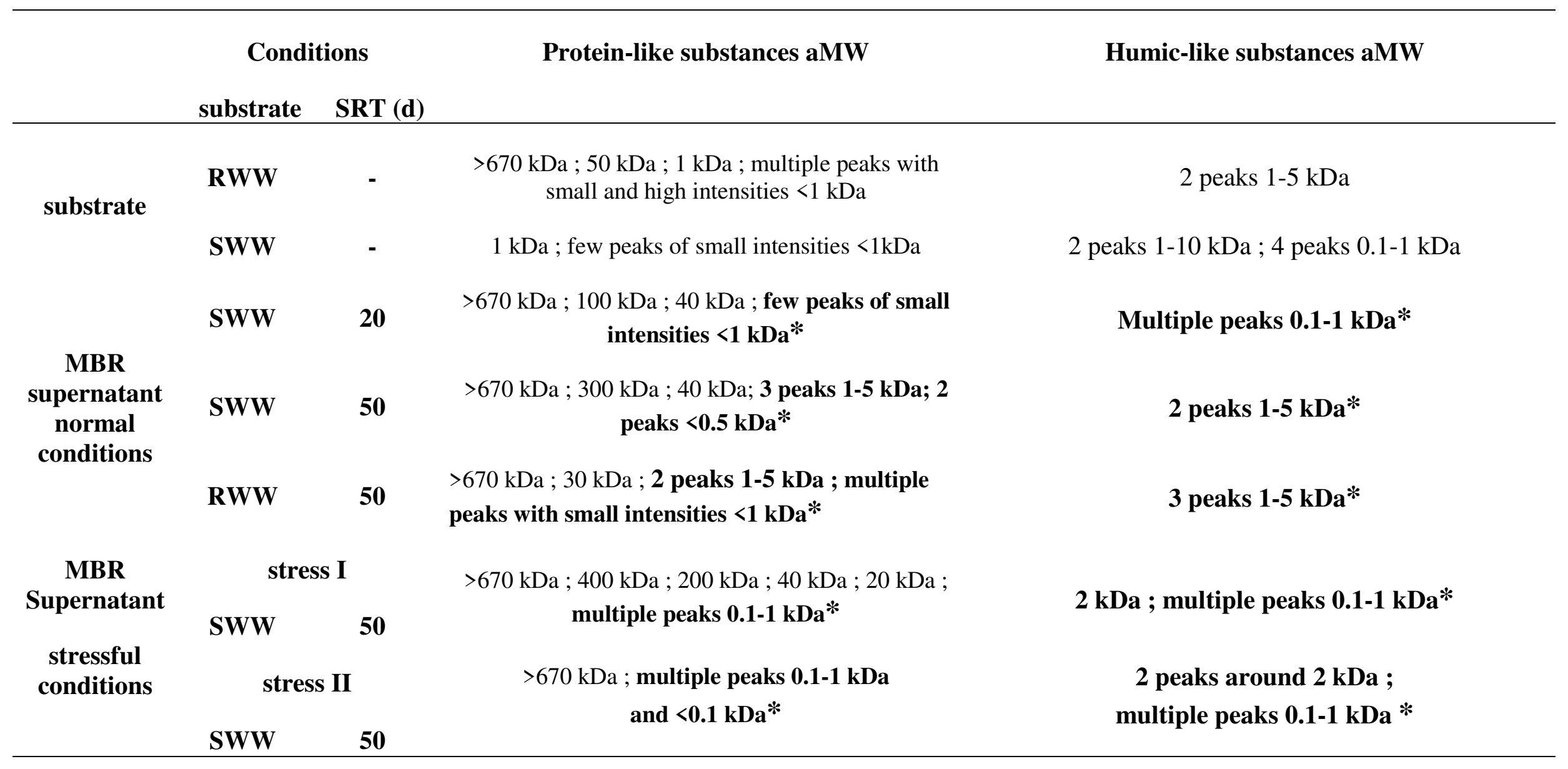

*aMW identified on respective permeate SEC chromatograms

Table 4 
Table 5

\begin{tabular}{|c|c|c|c|c|c|c|}
\hline \multicolumn{2}{|c|}{ Conditions } & \multirow{2}{*}{ TMP increase $\left(\mathrm{kPa} \mathrm{h}^{-1}\right)$} & \multirow{2}{*}{$\begin{array}{c}\text { Relative permeability loss } \\
\left(h^{-1}\right)\end{array}$} & \multicolumn{3}{|c|}{ Membrane fouling resistance (\%) } \\
\hline Substrate & SRT (d) & & & removable & irremovable & irreversible \\
\hline SWW & 20 & $0.015 \pm 0.013$ & $0.003 \pm 0.001$ & 12 & 85 & 3 \\
\hline SWW & 50 & $0.046 \pm 0.021$ & $0.004 \pm 0.001$ & 9 & 90 & 1 \\
\hline RWW & 50 & $0.022 \pm 0.020$ & $0.001 \pm 0.0007$ & 4 & 94 & 2 \\
\hline \multicolumn{2}{|c|}{ stress I } & $0.83 \pm 0.38$ & $0.074 \pm 0.003$ & $-*$ & $-*$ & $-*$ \\
\hline \multicolumn{2}{|c|}{ stress II } & No variation & $0.003 \pm 0.001$ & $-*$ & -* & $-*$ \\
\hline
\end{tabular}

* not measured 


\begin{tabular}{|llll|}
\hline Substrate type & SWW* & SWW & RWW* \\
SRT $(d)$ & 20 & 50 & 50 \\
Biomass state & Stable & Stable & Stable \\
\hline
\end{tabular}

* SWW and RWW : synthetic or real wastewater fouling layer specific to the substrate used
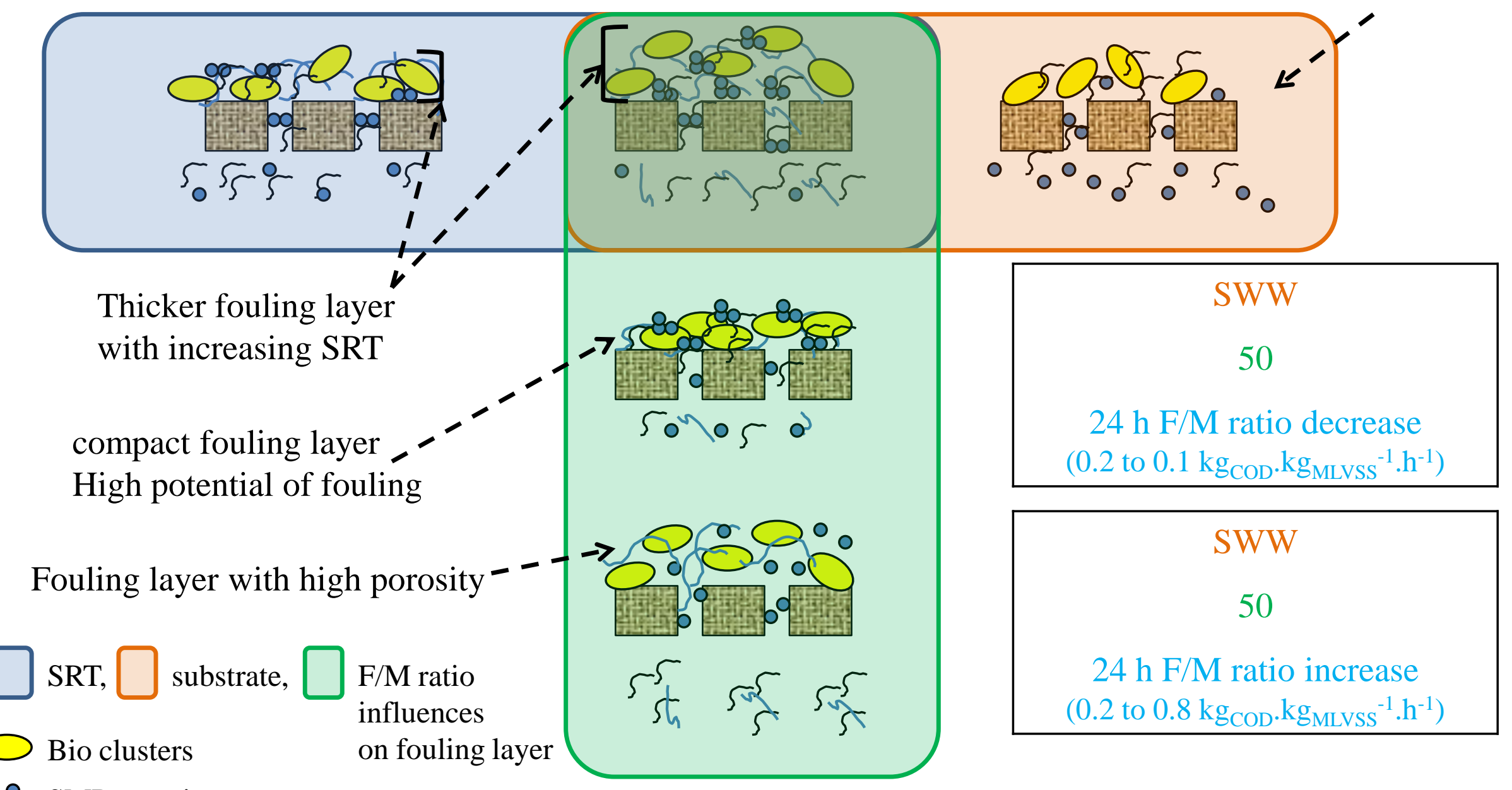

- SMP-proteins

SMP-polysaccharides

5 SMP-humic-like substances

Membrane fouling layer under various operating conditions 